\title{
The Role of the State in Providing Public Services for the Utilization of Marine Resources
}

\author{
Marlina Br Purba ${ }^{1,2}$, Lazarus Tri Setyawanta Rebala ${ }^{1}$, Nanik Trihastuti ${ }^{1{ }^{*}}$ \\ ${ }^{1}$ Department of Law, Faculty of Law, Diponegoro University, Semarang, Indonesia \\ ${ }^{2}$ Department of Law, Faculty of Law, University of Surabaya, Surabaya, Indonesia
}

Received June 16, 2021; Revised August 4, 2021; Accepted September 8, 2021

\begin{abstract}
Cite This Paper in the following Citation Styles
(a): [1] Marlina Br Purba, Lazarus Tri Setyawanta Rebala, Nanik Trihastuti, "The Role of the State in Providing Public Services for the Utilization of Marine Resources, "Environment and Ecology Research, Vol. 9, No. 5, pp. 209 - $214,2021$. DOI: 10.13189/eer.2021.090501.
\end{abstract}

(b): Marlina Br Purba, Lazarus Tri Setyawanta Rebala, Nanik Trihastuti (2021). The Role of the State in Providing Public Services for the Utilization of Marine Resources. Environment and Ecology Research, 9(5), 209 - 214. DOI: 10.13189/eer.2021.090501.

Copyright $\bigcirc 2021$ by authors, all rights reserved. Authors agree that this article remains permanently open access under the terms of the Creative Commons Attribution License 4.0 International License

\begin{abstract}
This paper aims to describe the role of the state in carrying out its public services for the utilization of natural resources by using the outlook of Indonesian philosophical insight of Pancasila in managing archipelagic state. This paper was conducted by using normative juridical approach to describe national management of marine resources. The management of marine resources is carried out through a legal framework to provide legal certainty and benefits for all communities as an archipelagic country characterized by an archipelago. The findings highlight that policies to maintain and manage marine natural resources, which will then be written about marine resources, must provide legal certainty and benefit value. The main contribution of this research is to explain the intersection of interests between uses within the national scope and at the same time containing the interests of use within the scope for the international community. This paper qualitatively examines the role of state as the main public service provider in administering institutions, corporations, independent institutions established by law for public service activities, and other legal entities established solely for public service activities in the context of utilization of marine resource. Empirical relationship between public sector performance and marine resource utilization was not tested in this study. The results encourage the state to maintain the integration of the nation and state both ideologically and territorially by realizing reliable public service through the improvement of utilizing marine resource as a means of increasing people
\end{abstract}

welfare, especially in an archipelagic state such as Indonesia. The description is in relation to the role of the state in implementing public services in the utilization of marine resources in an archipelagic country based on national insight.

Keywords Public Service, State Role, Marine Resource, Pancasila, Indonesia

\section{Introduction}

The state which is commonly identified with the government is also equated with the nation (natie), society, tax authorities or state treasury. In the study of international law, Mochtar \& Agoes [1] explained that the state is a subject of international law in a classical sense. There is still an opinion that international law is essentially the law between countries even though it is not only the state as a subject of international law. The subjects of international law include states, the holy throne, the international Red Cross, international organizations, individuals in a limited sense, rebels and disputing parties.

Realizing the state's goals of Indonesia is an obligation based on the five foundations of the state, namely Pancasila. As a nation's philosophical basis, Pancasila has a relationship of conformity with the state it is based on 
[2]. This suitability relationship has three components. The first is the base of the comparison which is used as the basis and measure to determine whether there is conformity. The second is the support of relations and the third is the principle of relationship which can be distinguished into the principle of relations, character relations, and causality. The basic elements of the relationship are the essential elements of God, man, one, the people, and just. The proponent of relations is the state, and the principle of the relationship is causation. The things that constitute the foundation of Pancasila, either directly or indirectly are the causes of the existence of the Indonesian state. As the basis of the state, Indonesia recognizes that without humans who are united as people who build the country to achieve justice with the blessing of God's power, Indonesia will not exist.

According to Alkostar [3], law in a country, including Indonesia, is a reflection of the dignity of the state, both nationally and internationally. It was also emphasized that the pillars of upholding the authority of the state are: (a) the state must feed its people; (b) the state must provide health facilities and transportation for its people; (c) the state must uphold justice for all citizens; (d) the state must be able to protect its territorial territory. If the four pillars cannot be upheld by the state, the state will lose its authority in the eyes of its people and the eyes of the international community [4,5]. Exposure for the sake of the presentation conveyed converged on a problem related to the role of the state in providing public services in the Indonesian archipelago with its Pancasila ideology in exploiting marine resources. The role of the state which is carried out with the five basic principles of Pancasila to realize the goals of the state with two aspects, namely the general goal in relation to problems between countries and specific goals, namely the national goal of realizing a just, prosperous, material, and spiritual society.

\section{Literature Review}

\subsection{Public Service}

According to Budiardjo [6], the state is an organization in an area that has the highest legal power and is obeyed by its people with the ability to influence in accordance with the wishes of the ruler. Public services according to Law Number 25 of 2009 are activities or series of activities in the context of fulfilling service needs in accordance with statutory regulations for every citizen and resident for goods, services, and/or administrative services provided by public service providers. Furthermore, it is regulated that the scope of public services in Article 5 paragraph (2) includes education, teaching, work and business, residence, communication and information, environment, health, social security, energy, banking, transportation, natural resources, tourism, and other strategic sectors.

This law is intended to provide legal certainty in the relationship between the public and administrators in public services with the aim of providing: (a) clear boundaries and relationships regarding the rights, responsibilities, obligations and authorities of all parties related to the delivery of public services; (b) the realization of a proper public service delivery system in accordance with the general principles of good governance and corporate governance; (c) the fulfillment of public service delivery in accordance with statutory regulations; (d) the realization of protection and legal certainty for the public in the provision of public services. Public services include services of public goods and public services as well as administrative services that are regulated in statutory regulations. The source of funding does not always come from the state budget, but also come from the availability based on the state mission as stipulated in the statutory regulations [7]. Thus, public service providers as regulated in Article 1 paragraph (2) state that the so-called administrators are any state administering institutions, corporations, independent institutions established by law for public service activities, and other legal entities established solely for public service activities [8]. At least the provision of public services includes: (a) implementation of services; (b) management of public complaints; (c) information management; (d) internal control; (e) outreach to the public; (f) consulting services.

As an example of public services to the marine, coastal and small island communities, the Denpasar Coastal and Marine Resources Management Agency (BPSPL). An organization carries out the policies and programs of the Directorate General of Marine Spatial Management 2015-2019. The vision of the Ministry of Marine Affairs and Fisheries for the management of marine space is "Management of Sovereign Marine Space and Sustainable Welfare". In line with that, the missions for the management of marine space are: (a) realizing an integrated coastal marine spatial planning and small islands; (b) utilize, protect and conserve marine, coastal and small islands resources as well as biodiversity management; (c) improve the management and control of marine, coastal and small islands space; (d) controlling the sovereign use of marine space for the welfare of the community.

Determined which are the main performance indicators as targets for the management of marine resources, coastal areas and small islands, including: (a) the number of locations for the sea, coastal areas and small islands that have a management plan; (b) the number of coastal areas facilitated with resilience to the threat of damage; (c) the number of protected and unprotected fish species is managed in a sustainable manner; (d) the number of small islands including the outermost small islands which are managed [9]. 
The performance indicators for BPSPL Denpasar are two (2) targets, namely the number of protected and unprotected fish species, and the number of marine, coastal and small islands locations that have a management plan. The result is the use of the Balanced Scorecards (BSC) method in 2013 as an effort to improve performance for the achievement of indicators whose direction is aimed at improving public services. It should be noted that the main characteristics of Indonesia is an archipelagic state. It leaves a number of problems, for example, state boundaries that have not been resolved and the existence of several zones where sharing interest applies. The role of the state is crucial in carrying out prime public services in order to achieve state goals with two aspects, namely general and specific.

\subsection{National Guideline in Directing the Management of Marine Resources}

In the context of state theory, the state is nothing more or less a collective entity-as an institutionalization of the public interest-exercising sovereign power. In 1945, when independence was proclaimed in Indonesia based on the spirit of national awakening (1908) and the Youth Pledge (1928), Indonesia emphasized its choice as a democratic nation state and wanted to continue to be united. As a nation-state, our country consists of various primordial ties (religion, ethnicity, race, region, language, culture, and customs) that want to unite (integration) firmly. The elements that make up the nationalism (nation) of Indonesia are historical unity, unity of fate, cultural unity, territorial unity, unity of religious principles [10,11].

Based on the explanation referred to as the country above, it can be concluded that the state is closely related to the concept of territory. One of the elements of the existence of a state must be territory, then in the territory there is also the highest authority which is legitimate and obeyed by the people, and the state has the sovereignty and power to regulate it, including regulating its territory.

In regulating its territory, Indonesia has the objectives listed in the fourth paragraph of the Preamble to the 1945 Constitution of the Republic of Indonesia. The definitive objectives of the Indonesian state are: to protect the entire nation and all the spilled Indonesian blood; promote the general welfare; enrich the life of a nation; and share in implementing world peace based on freedom, lasting peace and social justice. In this way Pancasila becomes a source that flows values and ideas about how Indonesian society should be organized. Pancasila is the deepest human and societal insight regarding the desired requirements in regulating social life, including regulating territoriality that embodies the goals of the Indonesian state [12]. Pancasila is a guideline in running the state in Indonesia. The principles used are the principle of an almighty Godhead, the principle of fair and civilized humanity, the principle of Indonesian unity, the principle of democracy led by wisdom in deliberation/representation, and the principle of social justice for all Indonesian people.

Kaelan [11] see that there are general goals and specific goals from the basis of the goal of the state. The general goal is to participate in implementing world order based on freedom, eternal peace and social justice. The intended general objective contains relations with problems between nations (international community association). The general objective which becomes the basis for the foreign policy of the Indonesian nation is based on the principle of being free and active. Its specific objectives are to protect the entire nation and all spilled Indonesian blood, promote public welfare, and educate the nation's life. Specific objectives include the national goal of forming a state with the aim of creating a just and prosperous society both materially and spiritually. Indonesia with the Pancasila ideology contains the stated goals of the country. Other countries with the ideology of Marxism-Leninism, for example, will aim to build a communist society. Its Bonum Publicum is to bring about a communist society. The state acts as a means of power to achieve goals according to its ideology. Every country, regardless of its ideology, will carry out a minimum number of absolute functions, including: (a) implementing law and order to achieve common goals and prevent clashes in society. The state must implement restraint and it can be said that the state acts as a stabilizer; (b) strive for the welfare and prosperity of its people; (c) defense to guard against possible external attacks; (d) enforcing justice that can be done through judicial bodies.

\section{Method}

This paper was conducted by using normative juridical approach to describe national management of marine resources. More specifically, this paper examines how Indonesia as an archipelago with the Pancasila ideology presents the role of the state in public services to utilize marine resources. As normative juridical approach, some regulations were used as a basis of analysis. The affirmation of the territory of the Unitary State of the Republic of Indonesia contained in article 1 number 1 of Law Number 43 of 2008 concerning the territory of the state, is one of the elements of the state which is a unitary land area, inland waters, archipelagic waters and territorial seas along with the seabed and the land under them, as well as the air space above it, including all sources of wealth contained therein. Apart from the territory of the state, it is also regulated with regard to jurisdiction in the provisions of article 1 point 3 , which is an area outside the territory of the country which consists of the Exclusive Economic Zone, Continental Shelf, and Additional Zone where the state has sovereign rights and certain other authorities as regulated in laws and regulations and 
international law.

The existence of regulations related to jurisdictional areas is an acknowledgment that Indonesia has sovereignty over its territory and has sovereign rights outside its sovereign territory. Sovereign rights give rise to certain powers to manage and utilize the natural resources contained therein for welfare and prosperity. It is affirmed in the provisions of article 3 of Law Number 43 of 2008 concerning the territory of the state which stipulates 3 (three) objectives of regulating the State Territory, namely: (a) guaranteeing the territorial integrity of the state, state sovereignty, and order in border areas for the benefit of the welfare of the whole nation; (b) enforce sovereignty and sovereign rights; (c) regulating the management and utilization of state territories and border areas, including the control of their boundaries.

\section{Results: Utilization of Marine Resources in Archipelagic Country}

As aquatic space is different in nature from space on land, the arrangements for preserving and managing its natural resources are also different. Where the management of marine resources is carried out through a legal framework to provide legal certainty and benefits for all communities as an archipelagic country characterized by an archipelago. This means that policies to protect and manage marine natural resources, which will then be written about the sea, must provide legal certainty and value benefits.

In Law Number 32 of 2014 concerning Maritime Affairs, the provisions of the sea are water space on the surface of the earth that connects land to land and other natural forms, which are geographic and ecological units along with all related elements, and whose boundaries and systems are determined by laws and regulations and international law.

Arrangements that provide legal certainty and benefit value in marine space are divided into zones according to international law. As is known, the international community's efforts to regulate maritime issues were signed in Montego Bay, Jamaica on December 10, 1982 by implementing UNCLOS (The United Nations Convention on the Law of the Sea) [13]. Furthermore, UNCLOS also regulates zones related to jurisdiction, authority and rights and obligations. These zones include: (a) the zone under the full sovereignty of a State: the territorial sea, the inland sea and the strait for international navigation with the right of passage in transit; (b) the zone applies special and limited jurisdiction in the additional zone; (c) zone of sovereign rights to exploit economic rights in the exclusive economic zone (EEZ) and the continental shelf; (d) zones under the control of international agencies in the international seabed; (e) a zone which is not under the control or sovereignty of any state on the high seas.

The determination of the zones has implications for different legal arrangements and authorities as well as the rights of the coastal State and other States as users and users. The form of sea regulation that is conditioned in an archipelagic country must also be adjusted to the interests of other countries. This means that the sea contains the use interests within the national scope and at the same time contains the use interests within the scope for the international community. In this case, it is represented by neighboring countries which have the nearest or adjacent borders. As an archipelagic country, Indonesia has an interest in regulating zones 1-3. Meanwhile, zones 4 and 5 do not have the authority of any country to regulate and control them. In the territorial sea, the coastal State has full sovereign boundaries followed by the right of peaceful passage, so that the coastal State has the right to make regulations regarding peaceful sea passage, which includes sea crossing regulations.

\section{Discussion}

For the State of Indonesia, the State's Objective is formulated in the Preamble to the 1945 Constitution that "the State protects the entire nation and all the blood of Indonesia" is a characteristic of a formal legal state and "advances the general welfare to educate the nation's life", as a characteristic of a material law state or welfare state. Meanwhile, in general, "participate in implementing world order based on eternal peace and social justice". Realizing this country's goal is the obligation of the Indonesian state as the highest organization of the Indonesian nation whose implementation must be based on the five principles of the state (Pancasila). From this it can be understood that Pancasila is the main guideline for state administration activities based on the principle of One Godhead, just and civilized humanity, Indonesian unity, democracy led by wisdom in deliberation/representation, and social justice for all Indonesian people [14].

In the context of the realization of the said goals of the Indonesian state, every state policy taken by state administrators must comply with the four principles of the ideals of law (rechtsidee) of Indonesia Pancasila, namely: (a) maintaining the integration of the nation and state both ideologically and territorially; (b) realizing the sovereignty of the people (democracy) and the rule of law (nomocracy) at the same time, as an inseparable unit; (c) realizing general welfare and social justice for all Indonesian people; (d) creating tolerance on the basis of humanity and being civilized in religious life [15]. The purpose of the State to protect the entire nation and all spilled Indonesian blood; Advancing public welfare to educate the life of the nation and participate in implementing world order based on eternal peace and 
social justice, whose implications are based on the five principles of Pancasila can be explained as follows.

First, God Almighty. This first precept is the basis of the state philosophy. It is a source of values and a source of norms in every aspect of state administration, both material and spiritual. In other words, all aspects of state administration must be in accordance with the nature of the values that come from God. It implies that there is a causal relationship between God, man and the state. This means that every public service policy that is taken must be accountable to God and contain moral values for the purpose of human goodness and happiness. The same is the case Tanya \& Bana [16] that the law is assigned to realize the bonum commune (realizing the common good) as the implementation of public services.

Second, justice and civilized humanity. This principle brings consequences in which all aspects of state administration, the principle of spirituality, the structure and state of the state must be coherent with the nature of human beings who are just and civilized. This means that for Indonesia there is recognition of the natural rights of humans as a nation and as individuals [17]. This means that the implementation of public services is not only intended for protection and certainty for its citizens, but also in maintaining good relations in international relations, especially in the middle of the intersection of interests between the use of the sea in the use of natural resources for national and international community [18, 19].

Third, Indonesian unity. The precept states that the Indonesian is a united nation. The essence of a united states is that the state is the society itself. In essence, the community represents itself in the administration of the state. In implementing public services, the state is able to bring awareness of multicultural morality. This means that there is a commitment to unifying views and goals in the midst of diversity. The condition in the field of exploitation of marine resources is called SWOT (strengths, weaknesses, opportunities and threats) become the reinforcement of the same commitment even in the midst of diversity [20].

Fourth, community leadership by the wisdom of wisdom in deliberation/representation, which means putting the interests of the people above the interests of the group. The people here are represented by all the Indonesian people, not just some. Relatively the obstacle is finding which interests of all the people. However, it is an effort to organize the public to explore the interests and needs of the Indonesian people which should be made a priority. The direction is clear, transparent and measurable. So that the output achieves results that can be felt together by coloring components of the state, people and regions, government and good relations in the international community [21]. This includes the implementation of public services for the use of marine space in the utilization of marine resources. Fifth, social justice for all Indonesian people, the realization of the protection of justice in living together requires the state to be a state based on law. With the fulfillment of three main conditions, namely: a). recognition and protection of human rights; b). free trial, and c). legality in the meaning of law in all its forms. This is aimed internally for all Indonesians, but also has implications for the international community.

\section{Conclusions}

As aquatic space is different in nature from space on land, the arrangements for preserving and managing its natural resources are also different. The management of marine resources is carried out through a legal framework to provide legal certainty and benefits for all communities as an archipelagic country characterized by an archipelago. This means that policies to maintain and manage marine natural resources, which will then be written about marine resources, must provide legal certainty and benefit value. It leaves a number of problems, for example, state boundaries that have not been resolved and the existence of several zones where sharing interest applies. The role of the state is crucial in providing excellent public services in order to achieve state goals. For the State of Indonesia, the State's Objective is formulated in the Preamble to the 1945 Constitution that "the State protects the entire nation and all the blood of Indonesia" is a characteristic of a formal legal state and "advances the general welfare to educate the nation's life," as a characteristic of a material law state or welfare state. Meanwhile, in general, "participate in implementing world order based on eternal peace and social justice." The realization of this country's goals is the obligation of the Indonesian state as the highest organization of the Indonesian nation whose implementation must be based on the five principles of the state (Pancasila). In the context of the realization of the said goals of the Indonesian state, every state policy taken by state administrators must comply with the four principles of the ideals of law (rechtsidee) of Indonesia Pancasila, namely: a) maintaining the integration of the nation and state both ideologically and territorially; b) realizing the sovereignty of the people (democracy) and the rule of law (nomocracy) at the same time, as an inseparable unit; c) realizing general welfare and social justice for all Indonesian people; d) creating tolerance on the basis of humanity and being civilized in religious life. The description is in relation to the role of the state in implementing public services in the utilization of marine resources in an archipelagic country based on Pancasila.

\section{REFERENCES}

[1] Mochtar K., Agoes E. R, "Introduction to International 
Law," Bandung: Alumni, 2003.

[2] Wahana P., "Philosophy of Pancasila," Yogyakarta: Kanisius, 1993.

[3] Alkostar A., "Concept and Implementation of the State of Pancasila Law in Overcoming National Legal Problems," Paper presented at the National Seminar, Semarang, September 30, 2017.

[4] Andriansyah, Sulastri E., Satispi E., "The role of government policies in environmental management," Research Horizon, vol. 1, no. 3, 2021.

[5] Setiyono J., Azhar M., Solechan S., Trihastuti N., Hakim A. R., "Justification of the ship-sinking policy in the territorial jurisdiction of Indonesia," AACL Bioflux, vol. 13, no. 5, pp. 2610-2618, 2020.

[6] Budiardjo M., "Fundamentals of political science," Jakarta: Gramedia Pustaka Utama, 2003.

[7] Trihastuti N., Putri S. A., Hananto P. W. H, "Prevention and management of marine pollution in malacca strait through the littoral states cooperation," Journal of East Asia and International Law, vol. 13, no. 2, pp. 379-396, 2020.

[8] Mahfud M., "Constitution and Law in Controversial Issues," Jakarta: RajaGrafindo Persada, 2012.

[9] Untoro U., Setyawanta L. T., Rahayu E. W., Raihan R., "Environmental and socio-legal assessments of the cultivation of non-consumed asian green mussel (Perna viridis) in the coastal areas of the jakarta bay," Journal of Environmental Treatment Techniques, vol. 8, no. 4, pp. 1498-1503, 2020.

[10] Notonagoro N., "Some things about the philosophy of Pancasila," Jakarta: Pantjuran Tujuh, 1967.

[11] Kaelan H. M. S., "Education of Pancasila," Yogyakarta: Paradigma, 2016.

[12] Halkis M., "Indonesian Political Constellation: Pancasila in Hermeneutic Phenomenological Analysis," Jakarta: Yayasan Pustaka Obor Indonesia, 2017.
[13] Suratman H., Samekto F. X. A., Trihastuti N., "The administration of small-scale economies in the cross-border trade in Southeast Asia," International Journal of Economics and Business Administration, vol. 8, no. 2, pp. 210-218, 2020.

[14] Hidayat A., "The State of Law with Pancasila Character," Paper presented on Guest Lecture Universitas Merdeka, Malang, July, 2017.

[15] Rahardjo S., "Legal education as human education," Law Reform, vol. 1, no. 1, pp. 1-10, 2009.

[16] Tanya B. L., Bana N. O., "Legal politics: common interest agenda," Yogyakarta: Genta Publishing, 2011.

[17] Adiansyah J. S., "Correlation Analysis between River Water Quality and Community Socio-Economic Condition: Case Study of Jangkok River, Mataram City," Inkalindo Environmental Journal, vol. 1, no. 1, pp. 49-61, 2020.

[18] Karmanovskaya N. V., Nosova O. V., Galishevskaya V. V., "Public Environmental Monitoring of the Quality of Water Bodies in Norilsk and Taimyr," Environment and Ecology Research, vol. 9, no. 2, pp. 45 - 63, 2021. DOI: 10.13189/eer.2021.090202.

[19] Samuel O., Dominic N., Patrick O., "Effects of Seasonal Variation on the Physicochemical Characteristics of Iyifeyi Stream in Ugwobi Abbi, Enugu State Nigeria," Environment and Ecology Research, vol. 8, no. 3, pp. 76 84, 2020. DOI: 10.13189/eer.2020.080303.

[20] Hananto P. W. H., Trihastuti N., Rizki D. M., Bismono R. C., "Rent Soil Theory V. Sustainable Development Goals in Indonesia: Environment Law Perspective," Environmental Policy and Law, (Preprint), pp. 1-7, 2020.

[21] Tienh A. L., Setiyono B., Soemarmi A., Trihastuti N., Setyawanta L. T., "Efforts in maintaining fisheries potential in the north natuna sea: Indonesian government policy against illegal, unregulated, and unreported fishing seen from the global maritime fulcrum perspective," AACL Bioflux, vol. 14, no. 3, pp. 1118-1125, 2021. 